\title{
SINTESIS DAN KARAKTERISASI ZIRKONIUM DIOKSIDA UNTUK DIGUNAKAN SEBAGAI MATRIK KOLOM GENERATOR RADIOISOTOP ${ }^{113 S n ~}-113 \mathrm{M} \mid n$
}

\section{SYNTHESIS AND CHARACTERIZATION OF ZIRCONIUM DIOXIDE FOR USE AS A GENERATOR MATRIX COLUMN ${ }^{113} \mathrm{Sn}$ - 113MIn RADIOISOTOPES}

\author{
Duyeh Setiawan*, Fuji Octa Indah Suciati \\ Pusat Sains dan Teknologi Nuklir Terapan, BATAN \\ Jl Tamansari No 71 Bandung 40132, TIp 022-2503997,faks 2504081 \\ e-mail :d_setiawan@batan.go.id
}

Diterima 7 Desember 2016, diterima dalam bentuk perbaikan13 Maret 2017, disetujui 13 April 2017

\begin{abstract}
ABSTRAK
SINTESIS DAN KARAKTERISASI ZIRKONIUM DIOKSIDA UNTUK DIGUNAKAN SEBAGAI MATRIK KOLOM GENERATOR RADIOISOTOP ${ }^{113} \mathrm{Sn}$ - 113m/n. Radioisotop ${ }^{113 m} / \mathrm{n}$ memiliki potensi untuk aplikasi di berbagai situasi industri sebagai pelacak untuk bahan cair, organik dan padat. Sistem dua fase yang terdiri dari padat dan cair sering ditemui di berbagai unit proses industri yang dirancang untuk memisahkan atau memurnikan suatu komponen. Memahami perilaku dari tahapan proses dalam industri adalah sangat penting untuk menyelidiki kinerja sistem. Radioisotop 113m/n dengan energi gamma $391 \mathrm{keV}$ dan waktu paruh 1,7 jam sangat ideal sebagai pelacak kedua fase tersebut, dapat digunakan untuk pengukuran langsung di sebagian besar industri. Radioisotop ${ }^{113 m} / \mathrm{n}$ diekstraksi dari generator ${ }^{113} \mathrm{Sn}$ - ${ }^{113 m} / \mathrm{n}$ menggunakan kolom matrik zirkonium dioksida dan eluen $\mathrm{HCl}$ untuk menghasilkan ${ }^{113 \mathrm{~m} / \mathrm{nCl}}$. Zirkonium dioksida dibuat dari zirkonil klorida $\left(\mathrm{ZrOCl}_{2} .8 \mathrm{H}_{2} \mathrm{O}\right)$ menggunakan metode presipitasi telah berhasil dilakukan, yaitu dengan mencampurkan zirkonil klorida dan amonia yang menghasilkan kristal $\mathrm{ZrO}(\mathrm{OH})_{2}$ dan air. Parameter proses yang dikontrol adalah $\mathrm{pH} 7$ dari larutan, sedangkan variabel yang dibandingkan adalah suhu perlakuan panas pada rentang $400-900^{\circ} \mathrm{C}$. Karakterisasi zirkonium dioksida hasil sintesis dilakukan dengan XRD diperoleh ukuran kristalit antara 12 - $15 \mathrm{~nm}$. Hasil SEM menunjukkan bentuk partikel zirkonium dioksida adalah spherical menuju granular. Sintesis zirkonium dioksida dengan metode reaksi pengendapan dapat mengontrol ukuran partikel, komposisi kimia yang diinginkan untuk digunakan sebagai matrik kolom generator radioisotop ${ }^{113} \mathrm{Sn}-113 \mathrm{~m} / \mathrm{n}$.
\end{abstract}

Kata kunci: generator ${ }^{113} \mathrm{Sn}$ - ${ }^{113 m} \mathrm{In}$, zirkonium dioksida, industri, radioperunut

\section{ABSTRACT}

SYNTHESIS AND CHARACTERIZATION OF ZIRCONIUM DIOXIDE FOR USE AS A GENERATOR MATRIX COLUMN ${ }^{113} \mathrm{Sn}$ - 113m/n RADIOISOTOPES. The radioisotope $113 \mathrm{~m} / \mathrm{n}$ has the potential for application in industrial using tracers as probes for aqueous, organic and solid material. Dual phase systems with solid liquid are often encountered in various industrial process unit that designed to separate or purify the components. Understanding the dynamic behaviour of each phase is very important in order to investigate the performance of the system. Radioisotopes $113 \mathrm{~m} / \mathrm{n}$ with gamma energies $391 \mathrm{keV}$ and a half-life of 1.7 hours is ideal as a tracer of the second phase, it can be used for direct measurement in most industries. Radioisotopes ${ }^{113 m} / \mathrm{n}$ extracted from the generator ${ }^{113} \mathrm{Sn}-113 \mathrm{~m} / \mathrm{n}$ using zirconium dioxide matrix column and $\mathrm{HCl}$ eluen to produce ${ }^{113 \mathrm{~m} / \mathrm{nCl}}$. Zirconium dioxide synthesis using precipitation method has successfully been done, by mixing zirconyl cloride and ammonia that produces crystal $\mathrm{ZrO}(\mathrm{OH})_{2}$ and water. Controlled synthesis process parameters are $\mathrm{pH} 7$ of solution while variables being compared are heat treatment temperature at the range of $400-900^{\circ} \mathrm{C}$. Characterization of zirconium dioxide result of synthesis was done with XRD is obtained crystallity size between $12-15 \mathrm{~nm}$. Result of SEM showed that zirconium dioxide particle is spherical to granular. Zirconium dioxide synthesis with reaction of precipitation method can be used to control particle size, chemical composition and morphology character wanted for used as a matrix column radioisotope generator ${ }^{113} \mathrm{Sn}-{ }^{113 m} / \mathrm{n}$.

Keywords: generator ${ }^{113} S n$ - $113 m / n$, zirconium dioxide, industry, radiotracer 


\section{PENDAHULUAN}

T eknologi radioperunut atau radiotracer digunakan dalam berbagai industri untuk mengoptimalkan proses, meningkatkan kualitas produk, menghemat energi dan mengurangi polusi. Penerapan metodologi radioperunut dapat berkontribusi kepada pengembangan ekonomi dan kemajuan teknologi di semua negara.

Penyediaan generator radiotracer (GRT), bisa menjadi pilihan yang menarik untuk mendapatkan yang diinginkan untuk kegiatan radiotracer di dekat lokasi penyelidikan di industri [1].

Bentuk GRT dengan sistem kolom kromatografi adalah paling cocok untuk digunakan dalam aplikasi berbagai industri karena mudah diadaptasi untuk digunakan dalam berbagai lingkungan. Pemilihan bahan sorben, merancang metode kimia untuk pemisahan radionuklida anak dari radionuklida induknya dan penggunaan larutan elusi merupakan faktor yang harus ditangani dalam mengembangkan GRT.

Di dalam pemanfaatan GRT ${ }^{113} \mathrm{Sn} / 113 \mathrm{~m} / \mathrm{n}$ pengembangan bahan sorben, merupakan parameter penting untuk keberhasilan kinerja dalam sistem generator. Setelah target ${ }^{112} \mathrm{Sn}$ diiradiasi oleh neutron melalui reaksi inti ${ }^{112} \mathrm{Sn}(n, \gamma){ }^{113} \mathrm{Sn}$. Kemudian dilarutkan dalam $\mathrm{HCl} 6 \mathrm{M}$, akan membentuk ${ }^{113} \mathrm{SnCl}_{4}$, selanjutnya teradsorpsi di dalam kolom kromatografi dengan matriks zirkonium dioksida $\left(\mathrm{ZO}_{2}\right)$ pada lingkungan $\mathrm{pH}$ 1,3-1,5 setelah diatur dengan larutan $\mathrm{NaCl}$ 3-4 M [2,3].

Metode pengendapan adalah salah satu teknik solusi yang paling banyak digunakan untuk sintesis zirkonium dioksida $\left(\mathrm{ZO}_{2}\right)$. Dalam proses pengendapan dari garam logam anorganik (misalnya klorida atau nitrat) apabila dilarutkan dalam air akan membentuk spesies logam hidrat seperti $\left[\mathrm{Zr}(\mathrm{OH})_{2} .4 \mathrm{H}_{2} \mathrm{O}\right]_{4}{ }^{2+}(\mathrm{OH})_{8}$, kompleks hidrokso [4]. Spesies ini dihidrolisis dengan menambahkan larutan basa $\left(\mathrm{NH}_{4} \mathrm{OH}\right)$ akan membentuk endapan logam hidroksida. Endapan kemudian dicuci, disaring dan dikeringkan, selanjutnya dikalsinasi untuk mendapatkan kristal akhir fase zirkonium dioksida $\left(\mathrm{ZrO}_{2}\right)$. Keuntungan dari proses pengendapan ini adalah relatif ekonomis dan dapat digunakan untuk mensintesis berbagai serbuk oksida tunggal dan multi komponen [5].

Zirkonium dioksida $\left(\mathrm{ZO}_{2}\right)$ tergolong material yang bersifat polimorf yang memiliki tiga macam struktur kristal yaitu monoklinik, tetragonal dan kubus. Zirkonium murni pada suhu kamar memiliki struktur kristal monoklinik $\left(\mathrm{m}_{-} \mathrm{ZrO}_{2}\right)$ dan bila terkena pemanasan sampai $1000-1100{ }^{\circ} \mathrm{C}$ akan berubah struktur kristalnya menjadi tetragonal $\left(\mathrm{t}-\mathrm{ZrO}_{2}\right)$. Karena pada kisaran suhu $1000-1100{ }^{\circ} \mathrm{C}$ masih tergolong fase yang tidak stabil dan bila didinginkan kembali pada suhu ruang akan berubah kembali menjadi monoklinik $\left(\mathrm{m}_{\mathrm{Z}} \mathrm{ZrO}\right)[6]$.

Oleh karena itu, $\mathrm{m}-\mathrm{ZrO}_{2}$ atau $\mathrm{t}-\mathrm{ZrO}_{2}$ hanya sesuai untuk aplikasi pada suhu rendah atau suhu ruang, akan tetapi $\mathrm{m}-\mathrm{ZrO}_{2}$ atau $\mathrm{t}-\mathrm{ZrO}_{2}$ memiliki kekuatan mekanik lebih tinggi dibanding dengan $\mathrm{c}-\mathrm{ZrO}_{2}$. Sedangkan c$\mathrm{ZrO}_{2}$ tergolong fasa yang paling stabil terhadap perubahan suhu. Untuk menstabilkannya struktur kristalnya sebagian atau seluruh perlu diubah ke fasa c- $\mathrm{ZrO}_{2}[7]$

Zirkonium dioksida sebagai matriks dalam generator kolom berperan meningkatkan densitas matriks yang memberikan kekuatan pada matriks agar lebih tahan terhadap kompresi dan perlakuan mekanis. Selain itu zirkonium dioksida, $\mathrm{ZrO}_{2}$ adalah bahan pendukung yang penting untuk katalisis dalam metode proses pemisahan karena bersifat mekanis dan stabilitas termal, daerah permukaan yang besar dan sifat asam basa. Zirkonium dioksida dapat juga diterapkan sebagai penyangga katalis yang menjanjikan, dapat digunakan di berbagai reaksi penting dalam industri seperti pengolahan air, oksidasi alkohol dan sintesis metanol $[8,9]$. Dalam bidang industri nuklir, bahan zirkonium oksida dapat digunakan sebagai matrik pada generator radioisotop ${ }^{188} \mathrm{~W} /{ }^{188} \operatorname{Re}[10]$.

Berdasarkan dari beberapa penggunaan senyawa polimerik zirkonium (PZC), maka $\mathrm{ZrO}_{2}$ tersebut perlu dikembangkan untuk generator radioisotop ${ }^{113} \mathrm{Sn} /{ }^{113 \mathrm{~m}} / \mathrm{n}$.

\section{METODOLOGI}

\section{Bahan}

Bahan kimia yang digunakan adalah zirkonium(IV)-oksida klorida oktahidrat ( E.Merck 1.08917.0100), amonium hidroksida (E.Merck 105432), asam klorida (E.Merck 1003161000), aquabides (Ipha), asam nitrat (E.Merck 100443.1000), perak nitrat (E.Merck 1015112.0025). Sedangkan alat gelas yang digunakan adalah gelas piala, labu erlenmeyer, labu ukur, gelas ukur, tabung sentrifugasi, pipet volum, pipet tetes, corong saring, corong buchner, termometer, kaca arloji, dan alat-alat gelas kimia yang biasa digunakan di laboratorium. 
Alat

Instrumentasi yang digunakan dalam melakukan penelitian ini antara lain, neraca analitik Ainsworth 24 $\mathrm{N}$, pipet mikro (Eppendorf) $100 \mu \mathrm{L}$ dan $5 \mu \mathrm{L}$, syring $1 \mathrm{~mL} ; 3 \mathrm{~mL}$ (Terumo), pH meter digital, kertas $\mathrm{pH}$ universal (E.Merck), vial $10 \mathrm{~mL}$ (Igar), magnetic stirrer (Thermolyne Nouva II), oven, Fourier-Transform Infra-Red (FT-IR), $X$-Ray Difraction (XRD) dan Scanning Electron Microscope (SEM).

\section{Cara Kerja}

\section{Sintesis zirkonium dioksida $\left(\mathrm{ZrO}_{2}\right)$ dengan metode presipitasi}

Sebanyak 2,67 mg ( $n=9)$ zirkonium(IV)-oksida klorida oktahidrat, $\mathrm{ZrOCl}_{2} .8 \mathrm{H}_{2} \mathrm{O}(\mathrm{ZN})$ dilarutkan dalam 50 $\mathrm{mL}$ air suling. Larutan kemudian ditambahkan $50 \mathrm{~mL}$ larutan amonia, $\mathrm{NH}_{4} \mathrm{OH}(2 \mathrm{~mL}$ amonia pekat dalam $48 \mathrm{~mL}$ air suling (LA). Penambahan larutan dengan cara $5 \mathrm{~mL}$ larutan ZN ditambahkan setiap 2 menit ke dalam larutan LA. Larutan kemudian diaduk dengan magnetik stirer pada variasi waktu dalam temperatur kamar. Untuk mengoptimalkan reaksi dilakukan variasi pengadukan selama 20 menit, 1, 3, 5, 7, 16, 20, 24, dan 28 jam (hasil yang terpilih sebagai waktu optimal). Endapan yang terbentuk berwarna putih dipisahkan dari larutan induknya dengan cara dekantasi dan larutan yang tersisa disaring. Selanjutnya endapan dicuci dengan air suling sampai bebas klorida (Pengujian bebas ion klorida( $\mathrm{Cl}$ ) menggunakan uji kualitatif dengan menambahkan pereaksi $\mathrm{AgNO}_{3} 0,1 \mathrm{~N}$ dan $\mathrm{HNO}_{3} 0,1 \mathrm{~N}(1: 1)$, jika larutan tidak keruh dan terjadi perubahan dari pH 11 menjadi pH 7, maka larutan sintesis zirkonium dioksida yang telah dibuat bebas ion klorida(11). Kemudian endapan dikeringkan dalam oven pada suhu $80^{\circ} \mathrm{C}$ selama 4 jam dan selanjutnya dibiarkan untuk mencapai suhu kamar. Kemudian endapan dengan rendemen yang optimum dikalsinasi dalam tungku pada berbagai suhu mulai 400, 500, 600, 700, 800 dan $900^{\circ} \mathrm{C}$ selama masing-masing 3 jam.

\section{Karakterisasi Zirkonium Dioksida $\left(\mathrm{ZrO}_{2}\right)$}

Sampel $\mathrm{ZrO}_{2}$ dikarakterisasi dengan X-ray Difraktometer (X-RD)-PW3040/60 X'Pert Pro dengan radiasi tembaga $\mathrm{X}$ - ray $(\mathrm{CuK} \alpha$ ) dengan panjang gelombang 1.54 Angstrom yang dihasilkan dalam difraktometer pada arus $15 \mathrm{~mA}$ dengan tegangan dari $30 \mathrm{kV}$ (PSTNT-BATAN). Dilakukan tingkat pemindaian adalah $2 \%$ menit. Ukuran kristal ditentukan dengan menggunakan persamaan Debye - Scherrer [13]. Karakterisasi memperkirakan permukaan serbuk $\mathrm{ZrO}_{2}$ menggunakan Scanning Electron Microscope (SEM) dan analisis energi dispersif X-ray dari sampel dilakukan pada SEM merk JEOL tipe JSM 6360LA 15kV pada pembesaran 10.000 dan 20.000 kali (tekMIRA). Karakterisasi menggunakan metode XRD dan SEM memberikan informasi mengenai morfologi atau ukuran kristal dari $\mathrm{ZrO}_{2}$ yang disintesis. Sedangkan ikatan kimia diidentifikasi menggunakan FTIR merk Shimadzu IR Prestige 21 (ITB). Identifikasi sampel menggunakan teknik pelet $\mathrm{KBr}$ dengan pengambilan data dari bilangan gelombang antara $4500-400 \mathrm{~cm}^{-1}$.

\section{HASIL DAN PEMBAHASAN}

\section{Sintesis Zirkonium Dioksida $\left(\mathrm{ZrO}_{2}\right)$ dengan Metode Presipitasi}

Sintesis zirkonium dioksida $\left(\mathrm{ZrO}_{2}\right)$ diperoleh dari mencampurkan larutan $\mathrm{ZrO}(\mathrm{Cl})_{2} .8 \mathrm{H}_{2} \mathrm{O}$ dengan larutan $\mathrm{NH}_{4} \mathrm{OH}$ pada perbandingan molar $(2: 3)$. Reaksi kimia yang terjadi seperti pada tahapan reaksi [5]:

$$
\begin{aligned}
& 2 \mathrm{ZrOCl}_{2}+3 \mathrm{NH}_{4} \mathrm{OH} \rightarrow \mathrm{ZrO}(\mathrm{OH})_{2}+\mathrm{ZrO}(\mathrm{OH}) \mathrm{Cl}+3 \mathrm{NH}_{4} \mathrm{Cl}_{2} \\
& \mathrm{ZrO}(\mathrm{OH}) \mathrm{Cl} \rightarrow \mathrm{ZrO}_{2}+\mathrm{HCl} \\
& \mathrm{ZrO}(\mathrm{OH})_{2} \underset{\uparrow}{\rightarrow} \mathrm{ZrO}_{2}+\mathrm{H}_{2} \mathrm{O} \uparrow
\end{aligned}
$$

Hasil pengujian waktu reaksi optimum dirangkum pada Tabel 1. Pada Tabel 1 ditunjukkan waktu reaksi optimum pembentukan $\mathrm{ZrO}_{2}$ adalah 24 jam dengan persen yield sebesar 81,20 \%. 
Tabel 1. Data hasil pengujian waktu reaksi optimum.

\begin{tabular}{llcccc}
\hline \multirow{2}{*}{ No } & Variasi waktu & Berat awal $(\mathrm{g})$ & Berat akhir $(\mathrm{g})$ & Berat teoritis $(\mathrm{g})$ & Yield $(\%)$ \\
\cline { 3 - 6 } & & $\mathrm{A}$ & $\mathrm{B}$ & $\mathrm{C}$ & $\mathrm{D}=\mathrm{B} / \mathrm{C}$ \\
\hline 1 & 20 menit & 2,6704 & 0,9456 & 1,8450 & 51,25 \\
2 & 1 jam & 2,6708 & 1,0522 & 1,8450 & 57,03 \\
3 & 3 jam & 2,6701 & 1,1632 & 1,8450 & 63,05 \\
4 & 5 jam & 2,6705 & 1,1827 & 1,8450 & 64,10 \\
5 & 7 jam & 2,6701 & 1,2399 & 1,8450 & 67,20 \\
6 & 16 jam & 2,6705 & 1,3482 & 1,8450 & 73,07 \\
7 & 20 jam & 2,6708 & 1,4059 & 1,8450 & 76,20 \\
8 & 24 jam & 2,6701 & 1,4982 & 1,8450 & 81,20 \\
9 & 28 jam & 2,6705 & 1,4953 & 1,8450 & 81,05 \\
\hline
\end{tabular}

\section{Karakterisasi Zirkonium Dioksida $\left(\mathrm{ZrO}_{2}\right)$}

Menurut Prasad et al, 2011 [5] tiga puncak utama dari $\mathrm{ZrO}_{2}$ adalah pada $2 \theta=29^{\circ} ; 30^{\circ} ; 31^{\circ}$.Gambar 1 (a) adalah pola $X$-ray Diffraction (XRD) $\mathrm{ZrO}_{2}$ hasil sintesis antara $2 \theta$ terhadap intensitas (\%) untuk setiap suhu perlakuan panas.

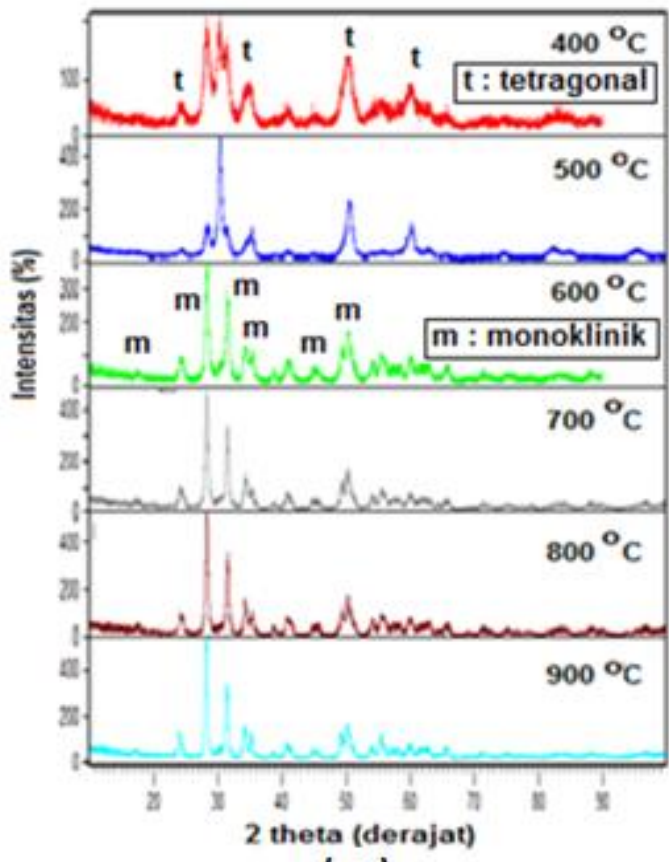

(a)

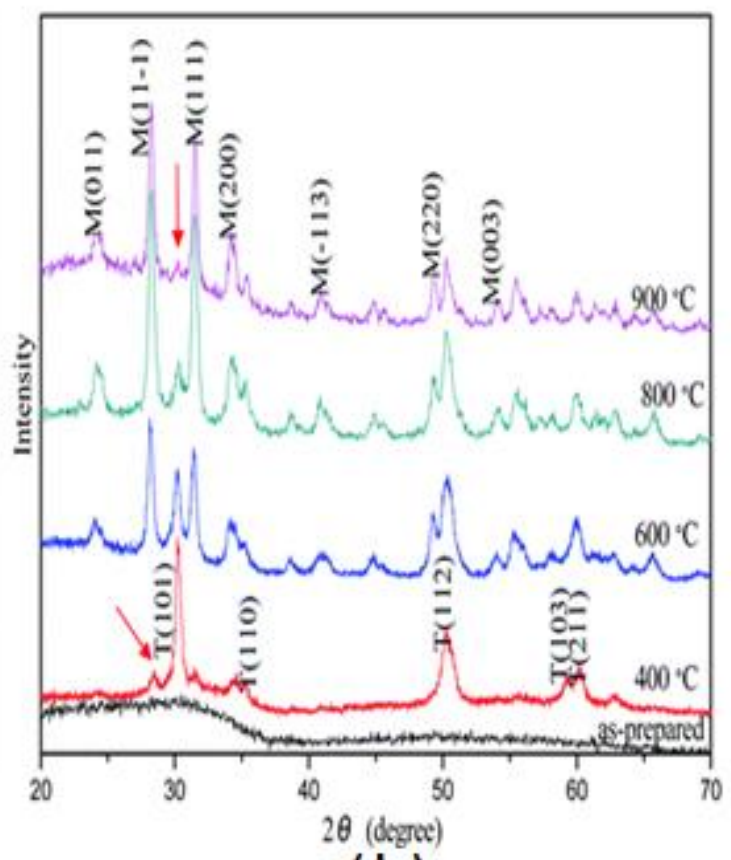

(b)

Gambar 1. Difraktogram X-ray diffraction (XRD) $\mathrm{ZrO}_{2}$ untuk suhu pemanasan yang bervariasi: (a) $\mathrm{ZrO}_{2}$ sintesis, (b) $\mathrm{ZrO}_{2}$ standard [12].

Dari hasil XRD didapat bahwa proses presipitasi menghasilkan zirkonium dioksida $\left(\mathrm{ZrO}_{2}\right)$ dibuktikan dengan difraktogram $\mathrm{ZrO}_{2}$ hasil sintesis (Gambar 1.a) yang memiliki kemiripan dengan difraktogram $\mathrm{ZrO}_{2}$ standar 
(Gambar 1.b). Zirkonium, $\mathrm{ZrO}_{2}$ tergolong material yang bersifat polimorfi yang memiliki tiga macam struktur kristal yaitu monoklinik, tetragonal dan kubus $\left(>1000^{\circ} \mathrm{C}\right)$. Zirkonium murni pada suhu kamar memiliki struktur kristal monoklinik $\left(\mathrm{m}_{\mathrm{Z}} \mathrm{ZrO}_{2}\right)$ dan bila terkena pemanasan $<600^{\circ} \mathrm{C}$ akan berubah struktur kristalnya menjadi tetragonal (t$\mathrm{ZrO}_{2}$ ). Pada kisaran suhu $600-900{ }^{\circ} \mathrm{C}$ masih tergolongfase yang tidak stabil dan bila didinginkan kembali pada suhu ruang akan berubah kembali menjadi monoklinik $\left(\mathrm{m}-\mathrm{ZrO}_{2}\right)[5,6]$.

Ukuran kristalit dari $\mathrm{ZrO}_{2}$ hasil sintesis dan perlakuan kalsinasi dihitung menggunakan metode Scherrer ${ }^{(13)}$, hasil ukuran kristalit $\mathrm{ZrO}_{2}$ seperti dirangkum pada Tabel 2 .

Tabel 2. Ukuran kristalit zirkonium oksida $\left(\mathrm{ZrO}_{2}\right)$ sintesis pada pH 7 untuk suhu kalsinasi yang bervariasi.

\begin{tabular}{cccc}
\hline No & $\mathrm{pH}$ & Suhu $\left({ }^{\circ} \mathrm{C}\right)$ & Kristalit $\left.(\mathrm{nm})^{*}\right)$ \\
\hline 1 & 7 & 400 & 12,86 \\
2 & 7 & 500 & 14,65 \\
3 & 7 & 600 & 15,75 \\
4 & 7 & 700 & 15,15 \\
5 & 7 & 800 & 14,36 \\
6 & 7 & 900 & 14,22 \\
\hline
\end{tabular}

Keterangan :

*) $L=k \lambda / B \cos \theta, L=$ diameter kristalit, $k=$ konstanta $(0.9), \lambda=$ panjang gelombang $k \alpha(0,154 \mathrm{~nm}), B=$ full width half maximum dari puncak $\mathrm{ZrO}_{2}$ (dalam radian), $\theta=$ posisi puncak.

Tabel 2 menunjukkan ukuran partikel $\mathrm{ZrO}_{2}$ hasil sintesis menggunakan metode presipitasi dan perlakuan kalsinasi antara $400-900^{\circ} \mathrm{C}$ adalah $12-15 \mathrm{~nm}$. Perlakuan kalsinasi di atas $900^{\circ} \mathrm{C}$ ukuran partikel cenderung menurun. Menurunnya ukuran kristalit diperkirakan terjadi karena disintegrasi partikel $\mathrm{ZrO}_{2}$ (didasarkan oleh tidak adanya perbedaan fasa yang terlihat pada hasil XRD). Perlakuan kalsinasi terhadap ukuran partikel $\mathrm{ZrO}_{2}$ yang memberikan ukuran yang hampir tetap adalah pada suhu mulai $600-700^{\circ} \mathrm{C}$.

Ikatan kimia $\mathrm{ZrO}_{2}$ hasil sintesa dan perlakuan kalsinasi diidentifikasi menggunakan FTIR seperti ditunjukkan pada Gambar 2.
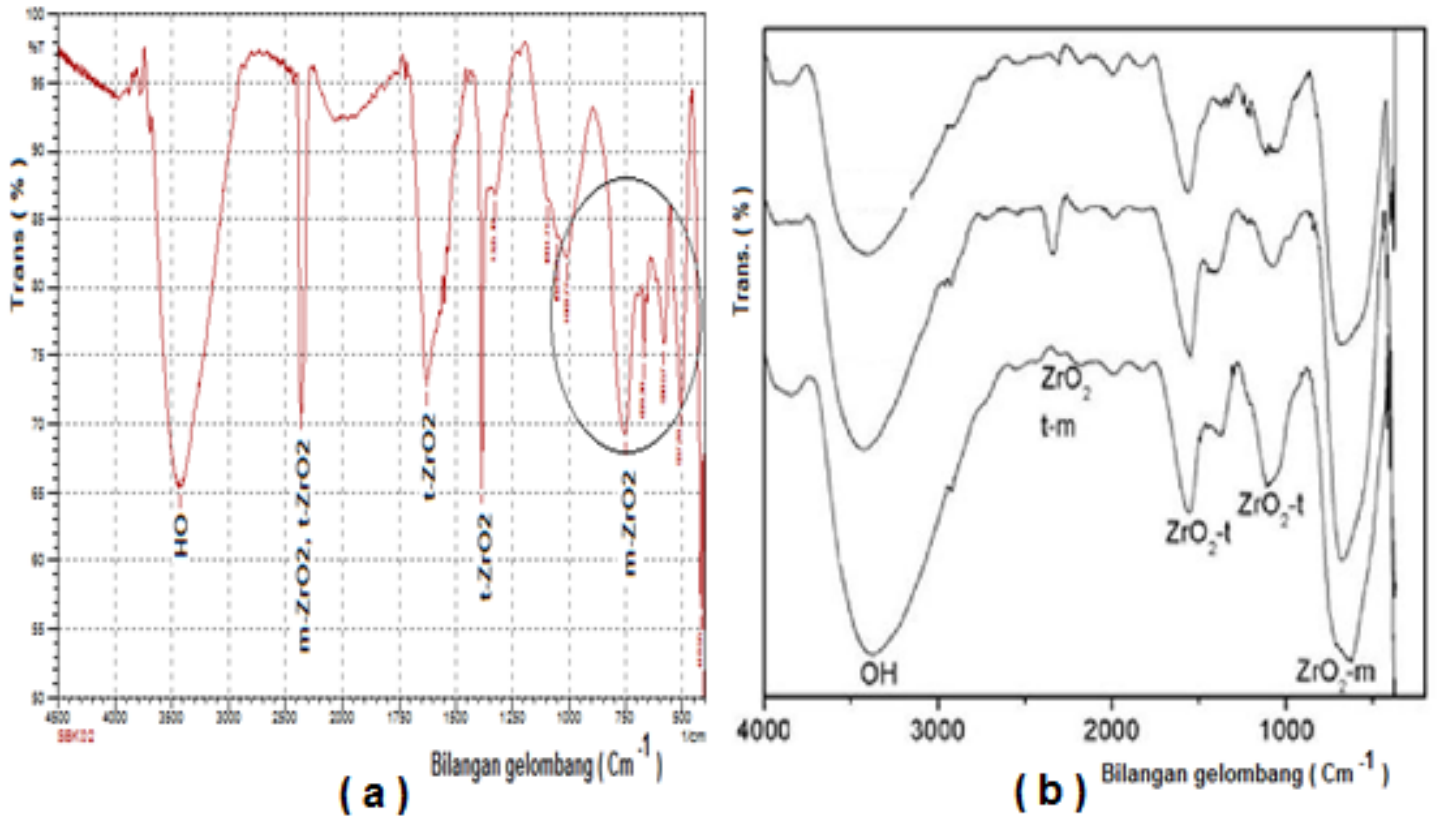

Gambar 2. Spektrum hasil uji FTIR: (a) $\mathrm{ZrO}_{2}$ sintesis pada pH 7, suhu kalsinasi $700^{\circ} \mathrm{C}$ (b) $\mathrm{ZrO}_{2}$ standar [14]. 
Gambar 2.a menunjukkan adanya gugus $\mathrm{OH}$-(ikatan $\mathrm{O}-\mathrm{H}$ pada puncak $\left.3427 \mathrm{~cm}^{-1}\right)$. Kelompok fase monoklinik $\mathrm{ZrO}_{2}\left(\mathrm{~m}-\mathrm{ZrO}_{2}\right)$ pada puncak $750 \mathrm{~cm}^{-1}$. Puncak 1385 dan $1626 \mathrm{~cm}^{-1}$ (fase tetragonal $\left.\mathrm{ZrO}_{2}, \mathrm{t}-\mathrm{ZrO}_{2}\right)$ dan $2338 \mathrm{~cm}^{-1}\left(\mathrm{~m}_{-2 \mathrm{ZO}_{2}}\right.$ dan $\left.\mathrm{t}-\mathrm{ZrO} \mathrm{Z}_{2}\right)$. Gugus-gugus ini merupakan suplemen bagi hasil analisa XRD yang menunjukkan bahwa hasil sintesis merupakan $\mathrm{ZrO}_{2}$. Gambar 2.b menunjukkan pola spektrum FTIR dari sampel $\mathrm{ZrO}_{2}$ standar.

Spektrum tersebut memiliki kemiripan dengan spektrum $\mathrm{ZrO}_{2}$ hasil sintesis pada Gambar 2.a. Adanya gugus $\mathrm{OH}^{-}$(ikatan $\mathrm{O}-\mathrm{H}$ pada puncak $\left.3550 \mathrm{~cm}^{-1}\right)$, kelompok fase monoklinik $\mathrm{ZrO}_{2}\left(\mathrm{~m}_{-} \mathrm{ZrO}_{2}\right)$ pada puncak $640 \mathrm{~cm}^{-1}$. Puncak 1269 dan $1595 \mathrm{~cm}^{-1}$ (fase tetragonal $\mathrm{ZrO}_{2}, \mathrm{t}-\mathrm{ZrO}_{2}$ ) dan $2338 \mathrm{~cm}^{-1}$ adalah fase $\mathrm{m}-\mathrm{ZrO}_{2}$ dan $\mathrm{t}-\mathrm{ZrO}_{2}$ ).

Morfologi $\mathrm{ZrO}_{2}$ hasil sintesis dan perlakuan kalsinasi didapatkan dari gambar SEM dengan perbesaran 3.000 kali, seperti ditampilkan pada Gambar 3.

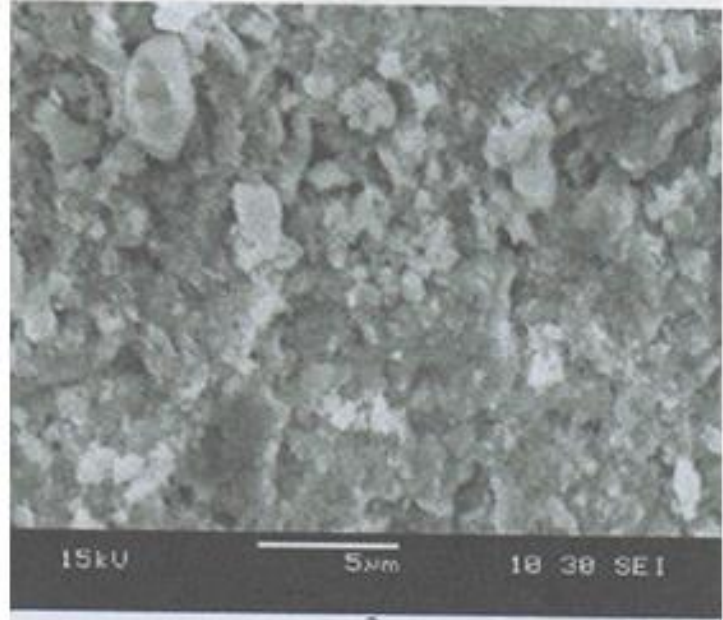

(a)

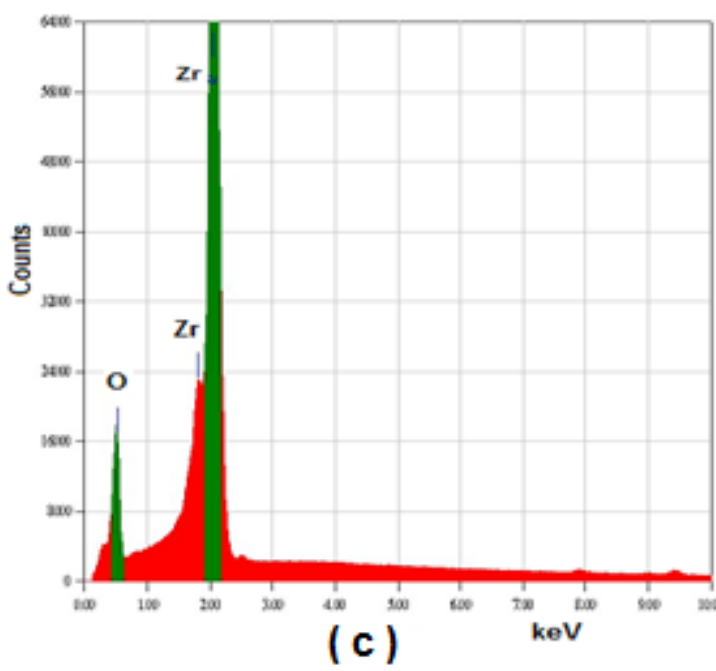

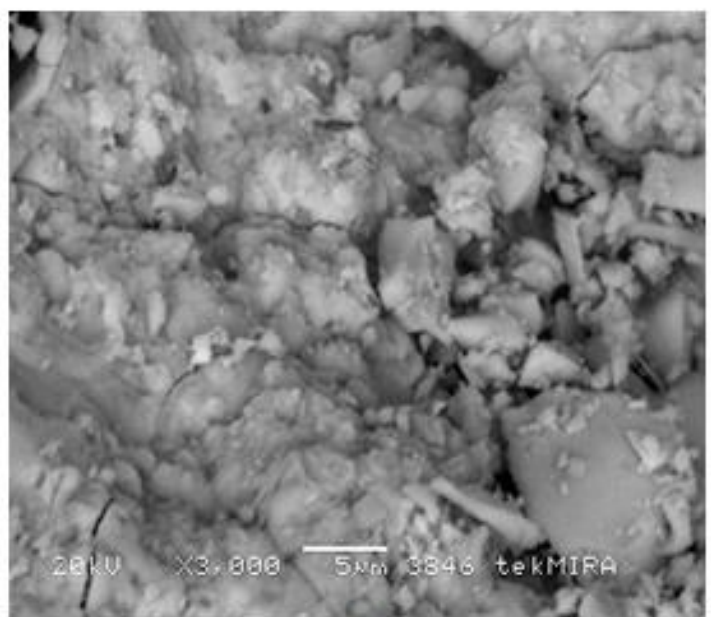

(b)

Gambar 3. (a) Morfologi $\mathrm{ZrO}_{2}$ standar(5), (b) $\mathrm{ZrO}_{2}$ sintesis pada $\mathrm{pH} 7$ suhu kalsinasi $700^{\circ} \mathrm{C}$ dan (c) grafik dan data analisis hasil pengukuran $\mathrm{EDX} \mathrm{ZrO}_{2}$.

Gambar 3 (b) menunjukkan adanya aglomerasi dari partikel-partikel tersebut, hal ini disebabkan oleh miskinnya dispersing agent sehingga partikel tetap teraglomerasi sejak pengeringan. Morfologi ini memiliki kemiripan dengan gambar 3 (a) untuk sampel $\mathrm{ZrO}_{2}$ standar, namun dengan aglomerasi yang lebih kecil.

Dari gambar 3 (b) tersebut dapat dilihat bahwa partikel $\mathrm{ZrO}_{2}$ berbentuk spherical menuju granular [4]. Bentuk granular merupakan hasil ripening (pemasakan) pada saat nukleisasi dan pertumbuhan kristal $\mathrm{ZrO}_{2}$, di mana umumnya sebuah partikel yang lebih besar akan mengintegrasi partikel yang lebih kecil di sekitarnya. Pada umumnya perbedaan hasil pengukuran morfologis dengan hasil perhitungan menggunakan metode Scherrer 
dapat disebabkan beberapa hal, antara lain pengukuran morfologis dilakukan dengan metode over estimate (diameter partikel yang diukur adalah sumbu terpanjang dari partikel) dan pengukuran morfologis dilakukan secara subjektif (partikel yang diukur hanya beberapa buah saja sehingga tidak representatif) [15].

Gambar 3 (c) merupakan hasil analisis kualitatif $\mathrm{ZrO}_{2}$ dengan metode energy dispersive $\mathrm{x}$-ray (EDX) yaitu untuk menentukan perbandingan komposisi unsur penyusun dari suatu material. Perhitungan dilakukan atas dasar rasio prosentase massa atom penyusun $\mathrm{ZrO}_{2}$. Gambar 3 (c) menunjukkan bahwa tidak ada kontaminasi dalam produk dengan puncak hanya zirkonium dan oksigen. Fraksi massa individu zirkonium dan oksigen dalam spesimen adalah $74,03 \%$ dan $25,97 \%$ yang sangat dekat dengan massa teoritis fraksi di $\mathrm{ZrO}_{2}$. Hasil perhitungan $\mathrm{ZrO}_{2}$ standar dan $\mathrm{ZrO}_{2}$ hasil sintesis memiliki perbandingan komposisi atom penyusun yaitu $\mathrm{Zr}$ dan $\mathrm{O}(1: 2)$. Perbandingan komposisi unsur hasil pengukuran EDX seperti dirangkum pada Tabel 3.

Tabel 3. Perbandingan komposisi unsur hasil pengukuran EDX.

\begin{tabular}{cccccc}
\hline Sampel & Unsur & Massa $(\%)$ & $\operatorname{Ar}(\mathrm{g} / \mathrm{mol})$ & Rasio mol & Rasio rumus empiris \\
\hline Sintesis & $\mathrm{Zr}$ & 74,03 & 91,22 & 0,81 & 1 \\
& 0 & 25,97 & 15,99 & 1,62 & 2 \\
\hline
\end{tabular}

Tabel 3 menunjukkan $\mathrm{ZrO}_{2}$ hasil sintesis memiliki kesamaan dengan $\mathrm{ZrO}_{2}$ standar [4]. Ukuran partikel $\mathrm{ZrO}_{2}$ hasil sintesis akan meningkatkan luas permukaan kontak dengan unsur-unsur sekitarnya pada saat dipergunakan. Dengan meluasnya permukaan kontak, maka ikatan antarmuka suatu unsur dengan $\mathrm{ZrO}_{2}$ akan meningkat. Material $\mathrm{ZrO}_{2}$ hasil sintesis mempunyai alternatif yang baik untuk digunakan sebagai matriks kromatografi kolom dalam sistem generator radioisotop.

\section{KESIMPULAN}

Zirkonium dioksida, $\mathrm{ZrO}_{2}$ disintesis dengan menggunakan metode presipitasi pencampuran asam dan basa pada $\mathrm{pH} 7$ berhasil dilakukan. Dari hasil sintesis, perlakuan panas serta karakterisasi diperoleh $\mathrm{ZrO}_{2}$ dengan ukuran partikel rata-rata antara $12-15 \mathrm{~nm}$. Bentuk partikel $\mathrm{ZrO}_{2}$ yang diperoleh adalah spherical menuju granular. Berdasarkan hasil karakterisasi, maka partikel $\mathrm{ZrO}_{2}$ hasil sintesis dapat dipergunakan untuk bahan absorben kolom generator dalam proses pemisahan radioisotop. Sintesis $\mathrm{ZrO}_{2}$ mempunyai keuntungan secara ekonomis karena dapat dibuat dari bahan kimia umum dan mudah didapatkan.

\section{UCAPAN TERIMA KASIH}

Ucapan terima kasih disampaikan kepada personel Kelompok Teknologi Proses Radioisotop, Nana Suherman, Titin Srimulyati yang telah membantu dalam kegiatan penelitian di PSTNT-BATAN Bandung.

\section{DAFTAR PUSTAKA}

[1] IAEA, Radiotracer Generators for Industrial Applications. IAEA Radiation Technology Series No.5. Vienna, (2013).

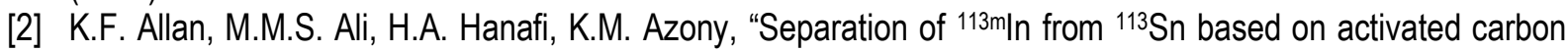
used as column matrix", J. Radioanal. Nucl.Chem, 284, 297-301 (2010).

[3] A.A. Abdel-Halim. Study on ${ }^{113} \mathrm{Sn}-{ }^{113 \mathrm{~m}} \mathrm{In}$ Generator of the Chromatographic Column Elution Mode. Thesis, Cairo Univ. (2002).

[4] A.N. Bugrov, Almjasheva, "Effect of hydrothermal synthesis conditions on the morphology of $\mathrm{ZrO}_{2}$ nanoparticles". Nanosystem: Physics, Chemistry, Mathematics, 4(6), 810-815 (2013).

[5] K. Prasad, D.V. Pinjari, A.B. Pandit, S.T. M. Haske, "Synthesis of zirconium dioxide by ultrasound assisted precipitation: Effect of calcination temperature". Journal Ultrasonics Sonochemistry, 8, 1128-1137 (2011). 
[6] DOI: 10.1016/j.ultronch.2011.03.001.

[7] R. Septawendar, B.S. Purwasasmita, Suhanda, L. Nurdiwijayanto, F. Edwin, "Nanocrystalline powder preparation using natural cellulosic material", Journal of Ceramic Processing Research, 12(1), 110-113 (2011).

[8] M.R. Gauna, S. Conconi, S. Gomes, G. Suarez, E.F. Aglietti, N.M. Rendtorff, "Monoclinic-tetragonal zirconia quantification of commercial nanopowder mixtures by XRD and DTA", J. Ceramics-Silikaty, 59(4), 318-325 (2015).

[9] Y. Vahidshad, H. Abdizadeh, H.R. Baharvandi, M.A. Baseri, "Sol gel synthesis and characterization of copper stabilized zirconia nanoparticle", Int. J. Mod. Phys, 25(21), 2823-2839 (2011).

[10] DOI: http://dx.doi.org/10.1142/S0217979211101119. Vahidshad et al, 2011.

[11] S. Asadia, H. Abdizadeh, Y. Vahidshad, "Effect of crystalline size on the structure of copper doped zirconia nanoparticles synthesized via sol-gel", Journal of Nanostructures, 2, 205-215 (2012).

[12] E. Iller, D. Wawczczak, M. Konior, H.P. Motrenko, J.J. Milczarek, L. Gorski, "Synthesis and structural investigation of gel metal oxid composites $\mathrm{WO}_{3}-\mathrm{ZrO}_{2}, \mathrm{WO}_{3}-\mathrm{TiO}_{2}, \mathrm{WO}_{3}-\mathrm{ZrO}_{2}-\mathrm{SiO}_{2}$ and their evaluation as material for the preparation of $188 \mathrm{~W} / 188 \mathrm{Re}$ generator", J. Applied Radiation and Isotopes, 75, 115-127 (2013).

[13] R.A. Sigwadi, S.E. Mayundla, N. Moloto, T. Mokrani, "Synthesis of zirconia-based solid acid nanoparticles for fuel cell application", Journal of Energy InSouthem Africa, 27(2), 60-67 (2016).

[14] D. Fang, K. Huang, Z. Luo, Y. Wang, S. Liu, Q. Zhang, "Freestanding $\mathrm{ZrO}_{2}$ nanotube membranes made by anodic oxidation and effect of heat treatment on their morphology and crystalline structure", J. Mater. Chem, 21, 4989-4994 (2011), DOI: 10.1039/C0JM03903A.

[15] A. Rachmania. "Preparasi Hidroksi apatit dari Tulang Sapi dengan Metode Kombinasi Ultrasonik dan Spray Drying". Tesis, FT UI, (2012).

[16] B. Reyes, M.E. Garcia, J.L. Sanchez, .I. Cabrera, F.J. Beltran, "Chemical anchorage of Hydroxyapatite on 316LSS using a $\mathrm{ZrO}_{2}$ interlayer for orthopedic prosthesis applications", J. Superficies $Y$ Vacio, 25(3), 150156 (2012).

[17] D. Setiawan, M. Basit, "Sintesis dan karakterisasi hidroksi apatit untuk aplikasi sinovektomi radiasi", Jurnal Forum Nuklir, 6(2), 120-126 (2012). 